\title{
The Ancestral Caddo Ceramic Assemblage from the Will Odham Site (41CE42) in the Angelina River Basin, Cherokee County, Texas
}

Timothy K. Perttula

Heritage Research Center, Stephen F. Austin State University

Follow this and additional works at: https://scholarworks.sfasu.edu/ita

Part of the American Material Culture Commons, Archaeological Anthropology Commons, Environmental Studies Commons, Other American Studies Commons, Other Arts and Humanities Commons, Other History of Art, Architecture, and Archaeology Commons, and the United States History Commons

Tell us how this article helped you.

This Article is brought to you for free and open access by the Center for Regional Heritage Research at SFA ScholarWorks. It has been accepted for inclusion in Index of Texas Archaeology: Open Access Gray Literature from the Lone Star State by an authorized editor of SFA ScholarWorks. For more information, please contact cdsscholarworks@sfasu.edu. 
The Ancestral Caddo Ceramic Assemblage from the Will Odham Site (41CE42) in the Angelina River Basin, Cherokee County, Texas

\section{Creative Commons License}

(c) (i) (8)

This work is licensed under a Creative Commons Attribution-NonCommercial 4.0 International License 


\section{The Ancestral Caddo Ceramic Assemblage from the Will Odham Site (41CE42) in the Angelina River Basin, Cherokee County, Texas}

Timothy K. Perttula

\section{Introduction and Setting}

The Will Odham site (ET-713) was recorded by Gus E. Arnold in March 1940 under the auspices of the WPA-sponsored archaeological survey of East Texas. The site was on an alluvial rise in the Big Turnpike Creek valley; Big Turnpike Creek is a tributary to Mud Creek in the Angelina River basin in the East Texas Pineywoods (Figure 1). The J. B. Maxwell site (41CE43), also recorded by Arnold, lies ca. $600 \mathrm{~m}$ northwest of the Odham site (Perttula 2017).

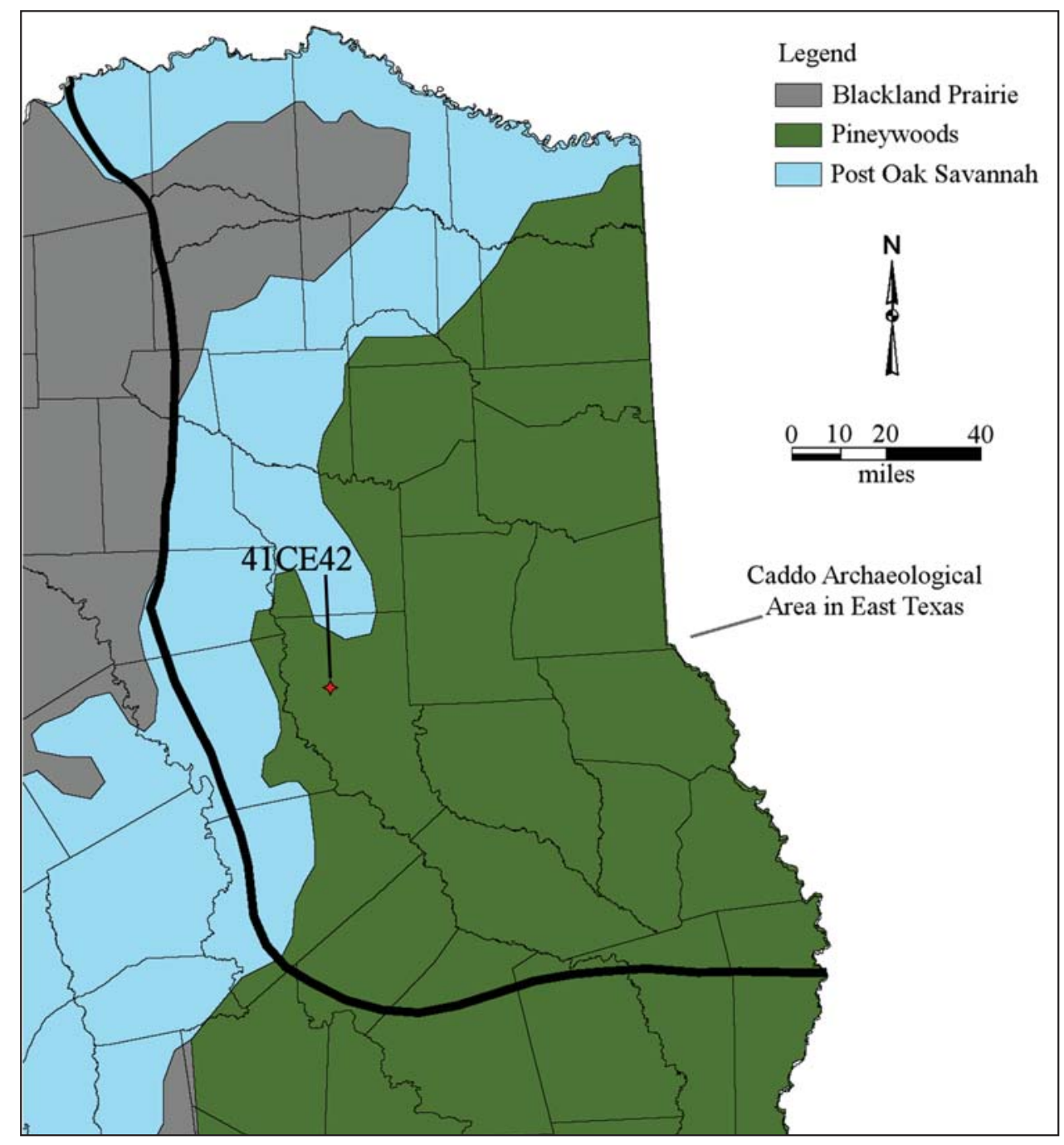

Figure 1. Location of the Will Odham site (41CE42) in East Texas. 
Archaeological deposits were estimated to cover a 5 acre area, but were concentrated in a ca. $60 \mathrm{~m}$ diameter area. These deposits had animal bone, mussel shells, ceramic vessel sherds, ground stone tools, and human skeletal materials. Burials had been reported to have been plowed up previously by the landowner in the eastern half of the site; the only known funerary objects reported associated with these burials were ceramic pipes.

\section{Ceramic Vessel Sherd Assemblage}

The large assemblage of ceramic vessel sherds from the Will Odham site is comprised principally of sherds in all three wares from grog-tempered vessels (Table 1). Approximately 89 percent of the sherds are from vessels tempered with grog inclusions, and the remaining 11 percent of the sherds are from bone-tempered vessels.

Table 1. Ceramic wares at the Will Odham Site (41CE42).

\begin{tabular}{lccc}
\hline Ware & Grog-tempered & Bone-tempered & N \\
\hline Plain & 709 & 95 & 804 \\
Utility & 703 & 78 & 782 \\
Fine & 65 & 9 & 74 \\
\hline Totals & 1477 & 182 & 1660 \\
\hline
\end{tabular}

The plain to decorated sherd ratio in the ceramic assemblage is 0.94 . More than 91 percent of the decorated sherds are from utility wares, and 57.5 percent of the decorated sherds have either brushed, brushed-incised, brushed-incised-punctated (Figure 2a-2b), or brushed-punctated decorative elements (Table 2) from Bullard Brushed vessels as well as untyped utility ware vessels; three of the brushedincised sherds with incised lines overlying the brushing marks may be from Spradley Brushed-Incised vessels, an East Texas Caddo ceramic type thought to have been made and used in post-A.D. 1680 times. The brushed to plain sherd ratio in the Will Odham site ceramic assemblage is 0.61 , and the brushed to other wet paste sherds ratio is 1.52 . The few fine ware sherds have either engraved ( 8.4 percent of all the decorated sherds) or red-slipped (0.2 percent) decorative elements (Table 2). 


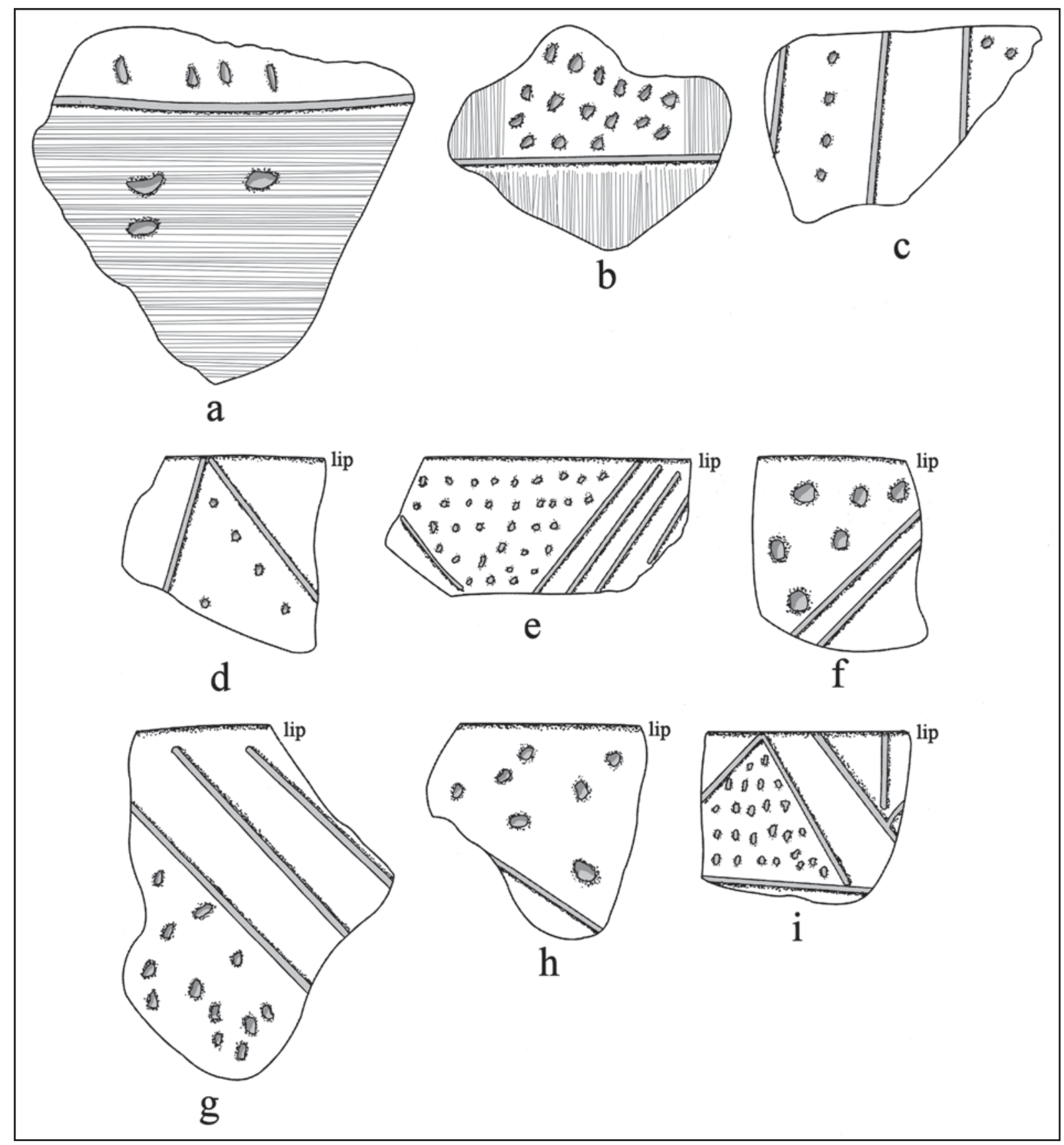

Figure 2. Selected decorative elements on utility ware sherds from the Will Odham site. 
Table 2. Decorative methods and elements in the utility ware and fine ware ceramic sherds from the Will Odham Site (41CE42).

\begin{tabular}{llll}
\hline $\begin{array}{c}\text { Decorative methods and } \\
\text { decorative elements }\end{array}$ & Rim & Body & $\mathrm{N}$ \\
\hline
\end{tabular}

\section{Utility Ware}

\section{Appliqued-Punctated}

large appliqued appendage and tool punctated rows

\section{Brushed}

diagonal brushed

horizontal brushed

opposed brushed

overlapping brushed

parallel brushed

vertical brushed

$\begin{array}{lll}3 & 3 & 6 \\ 4 & - & 4 \\ - & 17 & 17 \\ - & 15 & 15 \\ - & 413 & 413 \\ 2 & - & 2\end{array}$

\section{Brushed-Incised}

horizontal brushed with overlying diagonal incised lines

horizontal and diagonal incised lines above vertical

brushing marks

opposed brushed and straight incised line

parallel brushed-incised marks and lines

parallel brushed with overlying diagonal incised lines

parallel brushed with overlying opposed incised lines

\section{Brushed-Incised-Punctated}

horizontal incised line and adjacent tool punctated row, above horizontal brushed with tool punctations through the brushing

horizontal incised line and vertical panel filled with tool punctations, with vertical brushing marks above and below horizontal incised line parallel brushed with overlying incised lines and a linear tool punctated row through the brushing

\section{Brushed-Punctated}

opposed brushed with tool punctated row through the brushing

parallel brushed with fingernail punctated row through the brushing

parallel brushed with tool punctated row through the brushing

$\begin{array}{lll}- & 1 & 1\end{array}$

$\begin{array}{ll}- & 2\end{array}$

- 1

$\begin{array}{ll}- & 1\end{array}$

\section{Incised}

cross-hatched incised lines 
Table 2. Decorative methods and elements in the utility ware and fine ware ceramic sherds from the Will Odham Site (41CE42), cont.

\begin{tabular}{llll}
\hline $\begin{array}{c}\text { Decorative methods and } \\
\text { decorative elements }\end{array}$ & Rim & Body & N
\end{tabular}

diagonal opposed incised lines

horizontal and diagonal incised lines

opposed incised lines

parallel incised lines

parallel incised with overlying straight line

straight incised line

straight line and pendant incised semi-circle

vertical and diagonal incised lines

$\begin{array}{lll}2 & 2 & 4 \\ - & 1 & 1 \\ - & 8 & 8 \\ - & 25 & 25 \\ - & 1 & 1 \\ - & 23 & 23 \\ - & 1 & 1 \\ 1 & - & 1\end{array}$

\section{Incised-Punctated}

diagonal and parallel incised lines and a row of tool

punctates

horizontal and vertical incised lines above a row of

circular punctates

incised panels filled with circular punctates

incised panels filled with linear punctates

incised panels filled with tool punctates

incised triangle el. filled with circular punctates

incised triangle el. filled with linear punctates

incised triangle el. filled with tool punctates

straight incised line and adjacent zone of circular

punctates

straight incised line and adjacent zone of fingernail

punctates

straight incised line and adjacent zone of linear tool

.

$\mathrm{N}$

punctates

straight incised line and adjacent zone of tool

punctates

vertical incised line and adjacent linear tool punctated row

\section{Pinched}

curvilinear pinched ridges

diagonal opposed pinched ridges

vertical pinched ridges

4
8
1
23
1
1

Punctated

fingernail punctated rows

linear tool punctated rows

opposed linear tool punctated rows

singe tool punctation

tool punctated rows

$\begin{array}{lll}- & 47 & 47 \\ - & 4 & 4 \\ - & 1 & 1 \\ - & 1 & 1 \\ 6 & 94 & 100\end{array}$


Table 2. Decorative methods and elements in the utility ware and fine ware ceramic sherds from the Will Odham Site (41CE42), cont.

\begin{tabular}{|c|c|c|c|}
\hline $\begin{array}{l}\text { Decorative methods and } \\
\text { decorative elements }\end{array}$ & Rim & Body & $\mathrm{N}$ \\
\hline
\end{tabular}

\section{Fine Ware}

\section{Engraved}

closely-spaced curvilinear engraved lines closely-spaced parallel engraved lines circle el. and closely-spaced parallel engraved lines cross-hatched engraved diagonal zones cross-hatched and hatched diagonal zones curvilinear oval engraved el. diagonal engraved lines diagonal scroll lines excised bracket el. hatched engraved triangle el. horizontal engraved line horizontal and curvilinear engraved lines horizontal and diagonal engraved lines nested hatched triangle el. parallel engraved lines straight engraved line vertical hatched panels

Slipped ext. red-slipped $\begin{array}{ll}- & 2\end{array}$ $2-2$

Totals 48 808 856

The incised and incised-punctated sherds are all likely to have primarily come from Maydelle Incised vessels with several different kinds of decorative elements on vessel rims. Together, sherds with these decorative elements comprise 15.5 percent of all the decorated sherds from the site. Six body sherds are distinctive in that they have vertical incised panels that have been filled with one or more vertical rows of either circular, linear tool, or tool punctations (see Figure 2c). One set of Maydelle Incised vessels featured geometric elements, including cross-hatched, diagonal, diagonal opposed, and vertical-diagonal incised lines (see Table 2). The other set of Maydelle Incised vessels have incised triangle elements filled with either circular, fingernail, linear tool, or tool punctates (see Figure 2d-i).

Additional utility ware sherds in the Will Odham site ceramic assemblage include three rim or body sherds from Killough Pinched vessels ( 0.3 percent), one appliqued-punctated sherd ( 0.1 percent), and many sherds from punctated vessels (17.9 percent of the decorated sherds) (see Table 2). Most of the punctated sherds have rows (on the rim and/or the vessel body) of tool punctations ( 69 percent), and the other 31 percent have rows of fingernail punctations (see Table 2). 
The principal fine ware sherds are from Poynor Engraved rim (Figure 3a-g) and body sherds (Figures 4a-k and 5a-f) from carinated bowls; none of the Poynor Engraved sherds have had a red or white pigment rubbed in the engraved lines. There are also no sherds from Poynor Engraved, var.

Freeman vessels (see Perttula 2011: Figure 6-64h-i), thought to be the latest (i.e., ca. A. D. 1560-1680) variety of Poynor Engraved, at least in the upper Neches River basin. There are a few sherds from Hume Engraved vessels in the Will Odham fine wares; these have vertical or diagonal engraved panels filled with hatched and/or cross-hatched lines (Figures 41 and 5d, g).

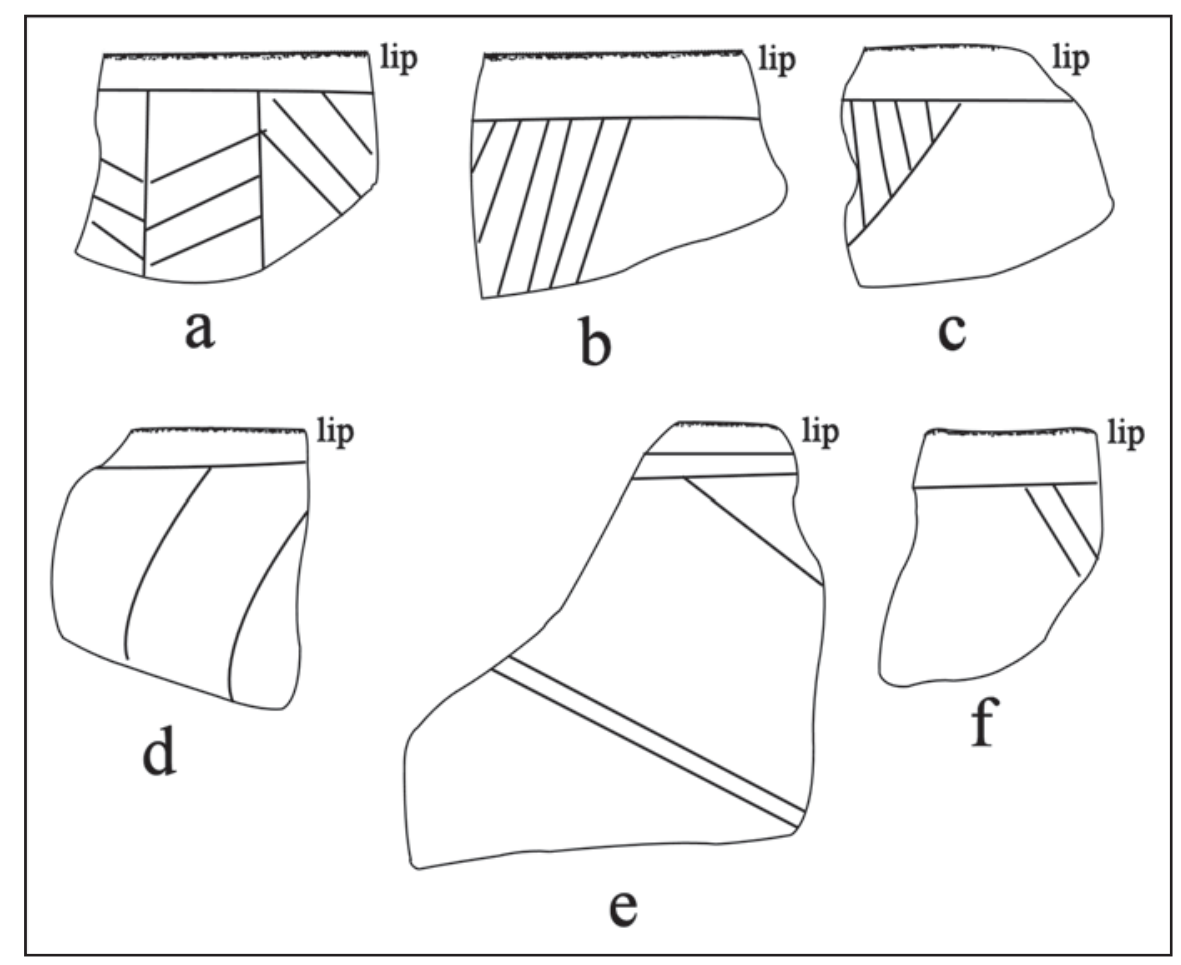

Figure 3. Selected decorative elements on Poynor Engraved rim sherds in the Will Odham site ceramic assemblage.

Most of the Poynor Engraved sherds have hatched triangle elements, including nested triangle elements (see Figure 4a) and hatched triangles associated with scroll lines (see Figures 3e and 5f. One Poynor Engraved, var. Hood body sherd (see Perttula 2011:Figure 6-64e) has excised bracket elements forming a negative oval, and one rim sherd from a Poynor Engraved, var. Cook vessel (see Perttula 2011:Figure 6-64c) has sets of curvilinear engraved lines forming large circular elements (see Figure 3d).

\section{Stamped-Incised Sherd}

A single grog-tempered body sherd with stamped-incised decorative elements may be from a Woodland period stamped vessel, possibly of Marksville or Troyville origin. Similar kinds of ceramics from Lower Mississippi Valley groups have been found in low densities in East Texas Woodland period sites (see Ellis 2013). The Will Odham sherd has a single stamped row and an adjacent diagonal incised line.

\section{Elbow Pipe Sherd}

The one grog-tempered elbow pipe sherd in the Will Odham site collections is part of the plain stem. The stem has a flat lip and is $4.2 \mathrm{~mm}$ thick. 


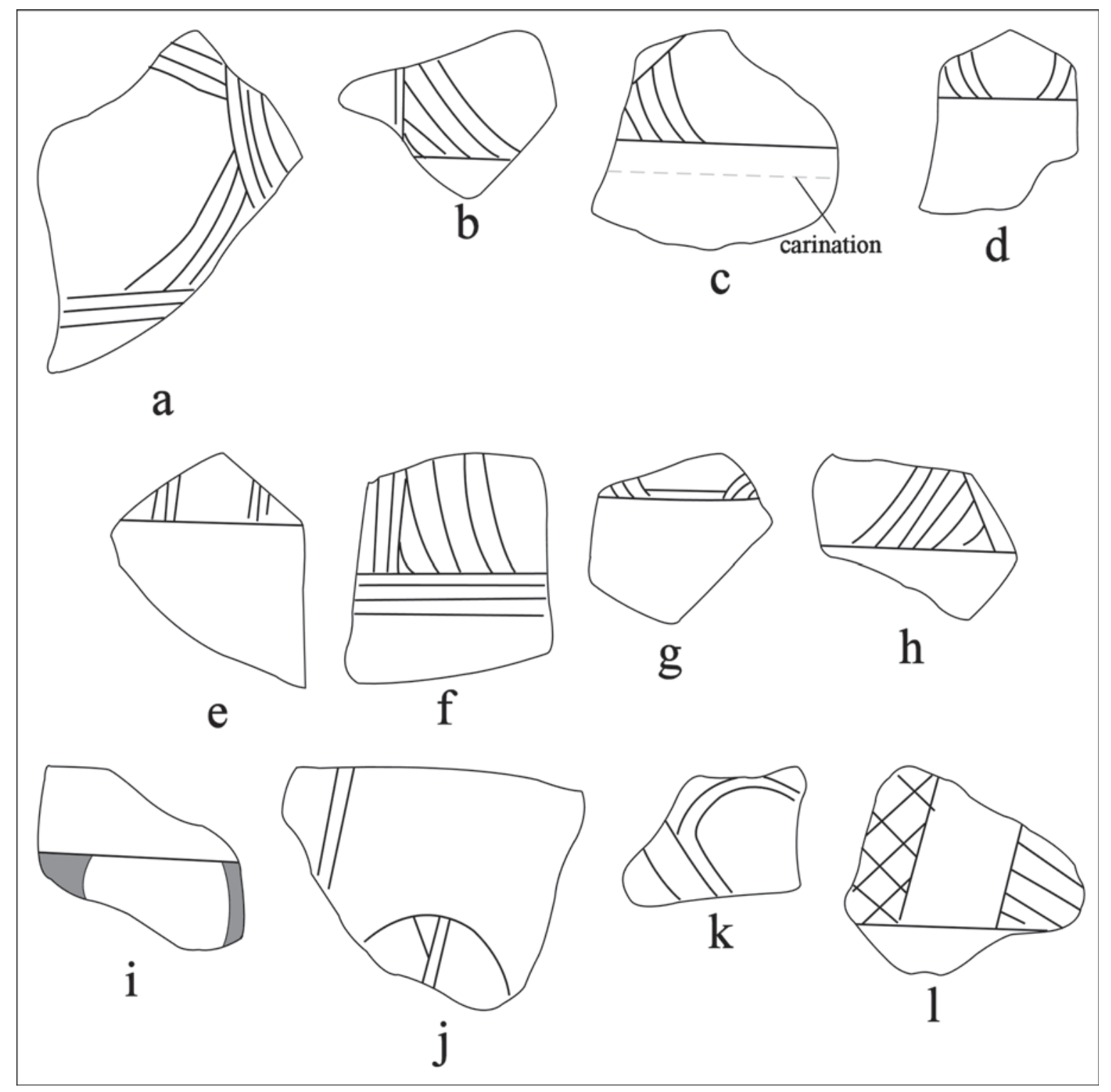

Figure 4. Selected decorative elements on Poynor Engraved and Hume Engraved body sherds in the Will Odham site ceramic assemblage.

\section{Summary and Conclusions}

The Will Odham site (41CE42) is an ancestral Caddo settlement in the Mud Creek drainage system, part of the Angelina River basin in East Texas. The site was recorded by Gus Arnold in March 1940 during the WPA archaeological survey of East Texas, and he obtained a substantial assemblage of ceramic vessel sherds and one plain elbow pipe sherd from habitation contexts.

The analysis of the ceramic vessel sherd assemblage from the site indicates that the vessels made and used there by Caddo peoples were primarily grog-tempered, and that the vessels (including bowls, carinated bowls, bottles, and jars) were plain ware, utility ware, and fine ware. The decorated sherds in the assemblage are primarily from brushed vessels (i.e., Bullard Brushed) -57.5 percent of the decorated sherds have brushing marks - but also identified in the utility ware ceramics are sherds from Maydelle Incised and Killough Pinched vessels, as well as a number of rim and body sherds decorated only with rows of fingernail 


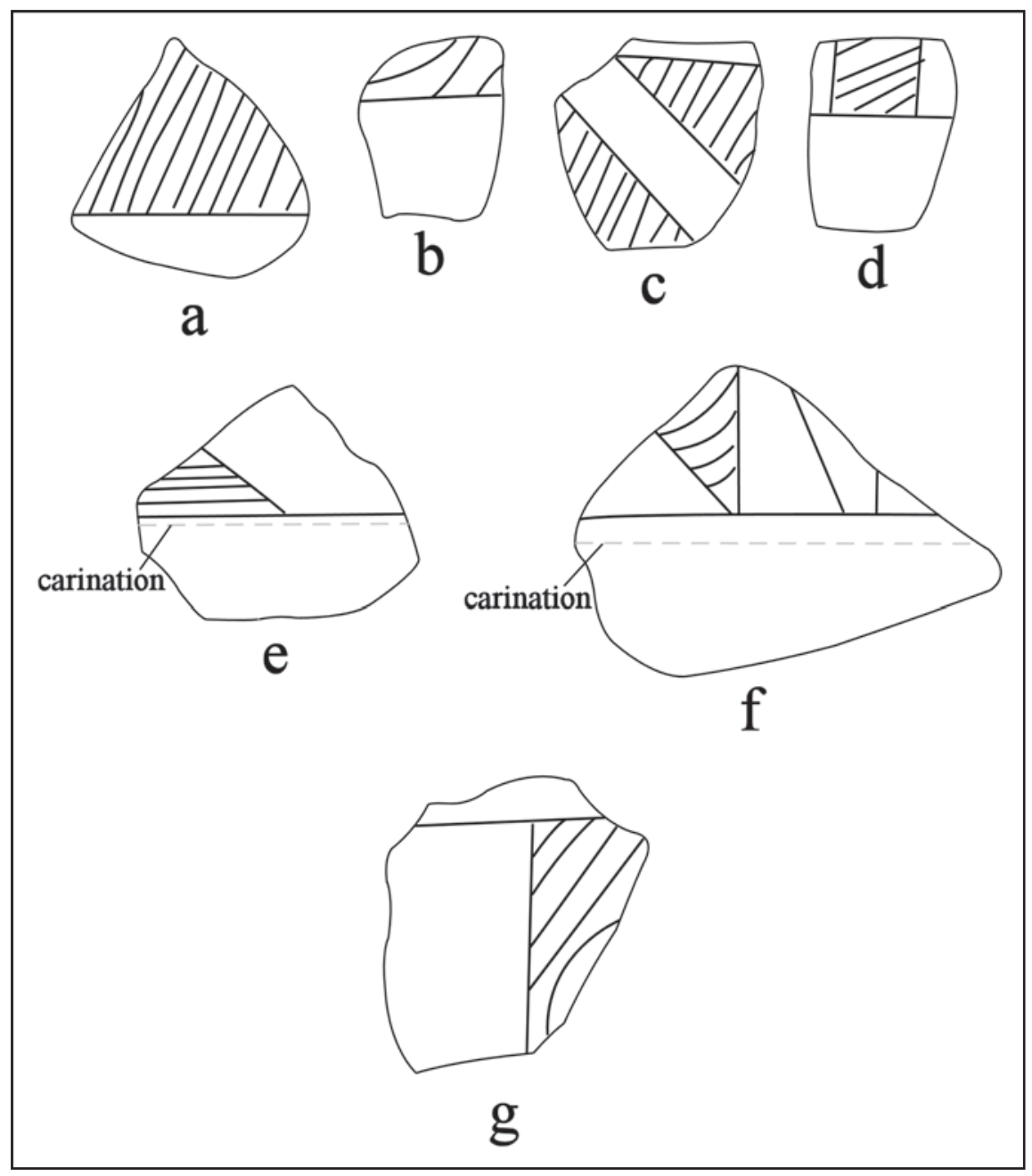

Figure 5. Other fine ware decorative elements on engraved body sherds in the Will Odham site ceramic assemblage, likely also from Poynor Engraved or Hume Engraved vessels.

or tool punctations. The fine ware sherds are from several varieties of Poynor Engraved vessels as well as Hume Engraved vessels. These various ceramic types indicate that the Will Odham site as occupied at some point during the Late Caddo period Frankston phase (ca. A.D. 1400-1680).

Ceramic attribute data, including the proportion of brushed sherds among all the decorated sherds, plain/decorated sherd ratios, brushed to plain sherd ratios, and brushed to other wet paste sherds ratio, from the Will Odham site suggest that the overall character of the assemblage is stylistically and socially related to both Neche cluster (Table 3) and upper Neches cluster (Table 4) sites in East Texas. These attributes, along with the kinds of Poynor Engraved varieties at the Will Odham site, suggest in particular that the occupation at the site is related to ancestral Caddo sites that predate ca. A.D. 1560 in both Neche and upper Neches clusters. The site's occupation is clearly older than the ancestral Caddo settlement at the nearby J. B. Maxwell site (41CE43) (see Table 3). 
Table 3. Ceramic sherd assemblage comparisons of Neche cluster sites with the Will Odham site (41CE42)

\begin{tabular}{|c|c|c|c|c|c|}
\hline Site & $\%$ Grog & $\%$ Bone & $\mathrm{P} / \mathrm{DR}$ & $\mathrm{B} / \mathrm{Pl}$ & $\mathrm{B} / \mathrm{OWP} * *$ \\
\hline \multicolumn{6}{|l|}{ Allen phase } \\
\hline \multicolumn{6}{|l|}{ Group I } \\
\hline$\overline{41 C E 293}$ & 98.1 & 5.6 & 0.12 & 7.50 & 5.70 \\
\hline 41CE43 & 96.1 & 3.9 & 0.17 & 4.91 & 6.08 \\
\hline 41CE477 & 95.8 & 4.2 & 0.18 & 4.73 & 13.0 \\
\hline 41CE474 & 97.1 & 2.9 & 0.30 & 3.08 & 9.25 \\
\hline \multicolumn{6}{|l|}{ Group II } \\
\hline 41CE48 & 84.2 & 27.7 & 0.31 & 2.43 & 5.48 \\
\hline 41CE475 & 91.2 & 9.2 & 0.34 & 2.55 & 11.3 \\
\hline 41CE20 & 85.7 & 14.3 & 0.40 & 2.07 & 5.0 \\
\hline 41CE476 & 91.2 & 9.2 & 0.45 & 1.77 & 7.0 \\
\hline 41CE291 & 97.4 & 2.6 & 0.30 & 1.94 & 1.84 \\
\hline \multicolumn{6}{|c|}{ Late Frankston phase (ca.A.D. 1560-1680) } \\
\hline \multicolumn{6}{|l|}{ Group III } \\
\hline \multicolumn{6}{|l|}{$\begin{array}{l}\text { Northern } \\
\text { part of site }\end{array}$} \\
\hline 41CE42 & 89.0 & 11.0 & 0.94 & 0.61 & 1.52 \\
\hline \multicolumn{6}{|c|}{ Possible Middle Caddo occupation, ca. A.D. 1300-1400 } \\
\hline \multicolumn{6}{|c|}{ Group IV } \\
\hline 41CE289 & 82.1 & 17.9 & 1.38 & 0.49 & 2.38 \\
\hline
\end{tabular}

$\mathrm{P} / \mathrm{DR}=$ plain to decorated sherd ratio; $\mathrm{B} / \mathrm{Pl}=$ brushed/plain sherd ratio; $\mathrm{B} / \mathrm{OWP}=$ brushed/other wet paste sherd ratio

Table 4. Comparative sherd assemblage data from upper Neches River basin Caddo sites.

\begin{tabular}{lllllll}
\hline Site & $\begin{array}{l}\text { No. of Dec. } \\
\text { Sherds }\end{array}$ & \% Brushed & $\begin{array}{l}\text { \%bone- } \\
\text { temper }\end{array}$ & $\begin{array}{l}\text { \% Wet-paste } \\
\text { decorations }\end{array}$ & P/DR & $\begin{array}{l}\text { Brushed/Wet } \\
\text { paste ratio }\end{array}$ \\
\hline GROUP II, latest & Frankston & phase, ca. A.D. & 1560-1680 & & \\
41HE22 & 228 & 85.5 & $?$ & 7.5 & 0.62 & 11.5 \\
41AN1 & 295 & 83.1 & 5.1 & 7.1 & 0.19 & 7.21 \\
41CE324 & 188 & 81.9 & 3.2 & 7.3 & 0.48 & 11.0 \\
Attaway & 814 & 84.4 & $?$ & 10.6 & 1.71 & 8.0 \\
Debro & 311 & 80.0 & $?$ & 10.3 & 0.14 & 7.75 \\
41SM91 & 191 & 75.9 & 0.7 & 14.7 & 0.51 & 5.18 \\
41AN21 & 133 & 75.9 & 1.1 & 17.1 & 0.30 & 5.32 \\
William & 525 & 75.8 & $?$ & 16.2 & 0.44 & 4.68 \\
Sherman & & & & & & \\
A. C. Saunders & 5805 & 74.5 & 15.5 & 14.4 & 0.21 & 5.30 \\
41AN8 & 98 & 70.4 & 3.3 & 18.3 & 0.55 & 3.83 \\
41AN2 & 152 & 67.8 & 11.5 & 17.8 & 0.41 & 3.81
\end{tabular}


Table 4. Comparative sherd assemblage data from upper Neches River basin Caddo sites, cont.

\begin{tabular}{|c|c|c|c|c|c|c|}
\hline Site & $\begin{array}{l}\text { No. of Dec. } \\
\text { Sherds }\end{array}$ & \%Brushed & $\begin{array}{l}\text { \%bone- } \\
\text { temper }\end{array}$ & $\begin{array}{l}\text { \% Wet-paste } \\
\text { decorations }\end{array}$ & $\mathbf{P} / \mathbf{D R}$ & $\begin{array}{l}\text { Brushed/Wet } \\
\text { paste ratio }\end{array}$ \\
\hline \multicolumn{7}{|c|}{ GROUP III, Frankston phase, ca. A.D. 1480-1560 } \\
\hline Forest Drive & 1693 & 68.6 & $?$ & 21.9 & 0.56 & 3.12 \\
\hline Halbert & 1757 & 65.8 & 2.6 & 26.3 & 0.70 & 2.51 \\
\hline Woldert & 1730 & 62.7 & 0.0 & 28.8 & 0.72 & 2.19 \\
\hline Ferguson & 4116 & 60.8 & $<1.0$ & 27.9 & 0.61 & 2.17 \\
\hline 41CE42 & 856 & 57.5 & 11.0 & 36.8 & 0.94 & 1.52 \\
\hline
\end{tabular}

The Will Odham site (41CE42) warrants relocation and restudy to examine its archaeological deposits and assess the potential to recover preserved material remains there, including charred plant remains and faunal remains as well as features with dateable organic remains, along with habitation features. The intensive archaeological survey of the Big Turnpike Creek valley in the Angelina River basin is also warranted because based on the ceramic data from both the Will Odham and J. B. Maxwell (41CE43) sites it is clear that the Big Turnpike Creek area was an important locus of ancestral Caddo settlement in East Texas from at least ca. A.D. 1480 to the early $18^{\text {th }}$ century.

\section{Acknowledgments}

Thanks to Lauren Bussiere at the Texas Archeological Research Laboratory at The University of Texas at Austin for access to the collections from the Will Odham site. Lance Trask prepared the figures in the article.

\section{References Cited}

Ellis, L. W.

2013 Woodland Ceramics in East Texas and a Case Study of Mill Creek Culture Ceramics. Bulletin of the Texas Archeological Society 84:137-180.

Perttula, T. K.

2011 The Ceramic Artifacts from the Lang Pasture Site (41AN38) and the Place of the Site within an Upper Neches River Basin Caddo Ceramic Tradition. In Archeological Investigations at the Lang Pasture Site (41AN38) in the Upper Neches River Basin of East Texas, assembled and edited by T. K. Perttula, D. B. Kelley, and R. A. Ricklis, pp. 145-320. Archeological Studies Program Report No. 129, Texas Department of Transportation, Environmental Affairs Division, Austin.

2017 The J. B. Maxwell Site (41CE43) in the Mud Creek Basin, Cherokee County, Texas. Journal of Northeast Texas Archaeology 71:155-159. 